\title{
OPTIMASI PENAMBAHAN KADAR MALTODEKSTRIN PADA PEMBUATAN BREM PADAT FLAVOUR JERUK
}

\section{Optimization of the Addition Maltodextrin Concentration on Making Solid Brem with Orange Flavour}

\author{
Mohammad Kharis Abdullah Afandy*, Simon Bambang Widjanarko \\ Jurusan Teknologi Hasil Pertanian, FTP Universitas Brawijaya Malang \\ Jl. Veteran, Malang 65145 \\ *Penulis Korespondensi, Email: kharisafandy@gmail.com
}

\begin{abstract}
ABSTRAK
Dalam satu kali proses pembuatan brem, banyak bahan baku yang terbuang dan rendemen yang dihasilkan sedikit. Oleh karena itu dibutuhkan alternatif pembuatan brem padat dengan penambahan maltodesktrin. Selain itu, produk brem padat selama ini belum mengalami perkembangan yang berarti, pengembangan produk brem padat dapat dilakukan dengan membuat brem padat aneka rasa.,dengan menambahkan flavor buah yaitu flavour buah jeruk manis. Penelitian ini menggunakan rancangan Center Composite Design metode permukaan respon (RSM) dengan satu faktor yaitu penambahan maltodekstrin dalam rentang $0 \%$ hingga $0.60 \%$. Hasil penelitian menunjukkan bahwa kondisi optimum penambahan maltodekstrin pada pembuatan brem terhadap respon rendemen (maksimum), total gula (maksimum), dan tekstur (in range) adalah penambahan maltodekstrin sebanyak $0.60 \%$. Analisa respon pada kondisi optimum menghasilkan rendemen $35.93 \%$, total gula $81.51 \%$, dan daya patah 41.85 $\mathrm{kg} / \mathrm{cm}^{2}$.
\end{abstract}

Kata kunci: Brem, Flavour Jeruk, Kondisi Optimum, Maltodekstrin

\begin{abstract}
The yield of Brem production is quite low and lot of raw materials was wasted. Therefore, it needs maltodextrin as an alternative to increase the amount of solid brem yield with good quality. On the other hands, solid brem product has no significant development. Brem production development can be done by creating a solid brem with various flavors, by adding fruit flavoring such as sweet orange fruit flavor. This research used Central Composite Design (CCD) with Respon Surface Methodology with one factor that was maltodextrin addition on range $0 \%-0.6 \%$. Result shows that the optimal condition of maltodextrin addition on brem production is $0.6 \%$. Respon analysis on optimal condition has $35.93 \%$ rendemen, $81.51 \%$ sugar total, and texture $41.85 \mathrm{~kg} / \mathrm{cm}^{2}$
\end{abstract}

Keywords: Brem, Maltodextrin, Optimum Condition, Orange Flavour

\section{PENDAHULUAN}

Brem adalah makanan tradisional hasil fermentasi yang dikenal sebagai makanan khas oleh-oleh kota Madiun yang memiliki karakteristik berwarna putih, tidak lembek, kering dan mudah hancur di mulut (Ariyanto, 2003).Bahan baku yang digunakan untuk membuat brem padat adalah beras ketan putih. Dalam satu kali proses produksi, para pengusaha brem biasanya menggunakan $12 \mathrm{~kg}$ beras ketan dan akan didapatkan brem padat sebanyak $2-2.4 \mathrm{~kg}$. Hal ini menunjukkan banyaknya bahan baku yang terbuang 
dan sedikit rendemen yang dihasilkan (20 - 25\%). Untuk mengatasi masalah tersebut, perlu dicari alternatif pembuatan brem padat dengan penambahan bahan tambahan pangan, namun kualitas yang dihasilkan tetap tinggi

Maltodesktrin merupakan salah satu bahan tambahan pangan yang sangat potensial digunakan dalam pembuatan brem padat, karena maltodekstrin sangat baik digunakan sebagai bahan pengisi untuk meningkatkan volume dalam sistem pangan (Hui, 1992). Selain itu, produk brem padat selama ini belum mengalami perkembangan yang berarti, baik dari rasa, bentuk maupun kemasan, sehingga pengembangan produk brem padat dirasakan perlu. Pengembangan produk brem padat dapat dilakukan dengan membuat brem padat aneka rasa (Hidayat, 2004). Pembuatan brem aneka rasa dapat dilakukan dengan menambahkan flavor buah yaitu flavour buah jeruk manis.

\section{BAHAN DAN METODE}

\section{Bahan}

Bahan - bahan yang dibutuhkan dalam pembuatan brem buah padat ini adalah beras ketan putih lokal (Oryza sativa var. glutinosa), ragi NKL (Na Kok Liong), buah jeruk manis, pereaksi Anthrone $0.1 \%$ dalam $\mathrm{H}_{2} \mathrm{SO} 4$ (asam sulfat) pekat, $\mathrm{CaCO}_{3}, \mathrm{~Pb}$-asetat, $\mathrm{Na}$-oxalate, dan aquades.

\section{Alat}

Alat - alat yang digunakan dalam pembuatan brem buah adalah timbangan, baskom plastik, panci, kompor gas, pengaduk kayu, tampah, kain saring, mixer, dan loyang. Sedangkan untuk analisis hasil produksi menggunakan alat seperti, Tabung Reaksi, Corong Kecil Pipet $1 \mathrm{ml}$ dan $5 \mathrm{ml}$, Waterbath $100^{\circ} \mathrm{C}$, Spektofotometer dan Kuvet, Color Reader Timbangan Analitik, Penetrometer, Gelas Beaker, Kertas Whatman".

\section{Tahapan Penelitian}

Penelitian dilakukan dengan menggunakan 2 tahapan yaitu penelitian pendahuluan dan penelitian utama. Penelitian pendahuluan bertujuan untuk menentukan dan mengetahui batasan variabel bebas dalam proses pembuatan brem yaitu proporsi sari buah yang digunakan serta titik tengah penambahan maltodekstrin. Proporsi sari buah yang didapatkan pada penelitian pendahuluan sebesar $25 \%$.

Penelitian utama yang dilakukan adalah tahap optimasi menggunakan Respon Surface Methodology dengan program Design Expert 7.1.5. Pemilihan proses optimasi ini dikarenakan mampu mendapatkan titik optimum yang sesuai dengan kriteria yang di inginkan tanpa harus melakukan running penelitian yang lebih banyak. Kemudian pada tahap validasi, hasil optimum dilakukan untuk membuktikan apakah solusi titik optimum variabel bebas yang diberikan program Design Expert benar-benar dapat memberikan hasil respon yang sesuai serta akan di analisa lanjutan dari proses optimum setelah dilakukan validasi

\section{Metode}

Proses optimasi dilakukan dengan rancangan Center Composite Design metode Respon Surface Methodology (RSM) menggunakan 3 center point dan menghasilkan 9 perlakuan percobaan setelah dioperasikan dengan menggunakan aplikasi Design Expert 7.1.5. menggunakan titik minimum $0 \%$ dan $0.6 \%$ sebagai titik maksimum,selanjutnya masing-masing percobaan dilakukan analisa respon. Respon yang digunakan dalam penelitian ini adalah total gula, rendemen, dan daya patah. Hasil penambahan maltodesktrin yang paling optimum selanjutnya akan dianalisa secara kimia dan fisik dan dibandingkan dengan brem kontrol. 


\section{Prosedur Analisis}

Analisis dilakukan pada brem padat yang dihasilkan dari masing-masing perlakuan yang didapatkan dari aplikasi Design Expert 7.1.5. Pengamatan yang dilakukan terhadap brem padat adalah rendemen, total gula dan daya patah.

Analisis terhadap brem hasil optimasi dari respon rendemen, total gula dan daya patah. Pengamatan yang dilakukan antara lain analisis kadar air, total gula, total asam, daya patah, dan kecepatan larut, masing-masing analisis diulang 3 kali.

Analisis pada brem kontrol yang ada di pasaran, guna untuk membandingkan sifat fisik-kimia terhadap brem hasil respon maksimum. Brem kontrol yang digunakan adalah merk "Brem Suling Gading". Pengamatan terhadap brem kontrol meliputi analisis kadar air, total gula, total asam, daya patah, dan kecepatan larut, masing-masing analisis diulang 3 kali.

\section{Analisis Bahan Baku}

\section{HASIL DAN PEMBAHASAN}

Bahan baku pada penelitian ini adalah beras ketan putih. Beras ketan putih difermentasi terlebih dahulu selama 7 hari kemudian diambil filtratnya untuk dijadikan bahan pembuatan brem.

Tabel 1. Komposisi Kimia Filtrat Tape Ketan

\begin{tabular}{lcc}
\hline \multirow{2}{*}{ Komponen } & \multicolumn{2}{c}{ Filtrat Tape Ketan } \\
\cline { 2 - 3 } & Hasil Analisa & Literatur \\
\hline Kadar Air (\%) & $65.21 \pm 0.25$ & $62.56^{\mathrm{a}}$ \\
Kadar Pati (\%) & $2.36 \pm 0.019$ & $0.817^{\mathrm{a}}$ \\
Total Gula (\%) & $65.80 \pm 0.002$ & $63.48^{\mathrm{a}}$ \\
Total Asam (\%) & $0.436 \pm 0.007$ & $0.493^{\mathrm{a}}$ \\
\hline
\end{tabular}

Keterangan : ${ }^{a}$ Setyorini (2003)

Kadar air filtrat tape ketan hasil analisa pada Tabel 1 sebesar $65.21 \%$. Menurut (Setyorini, 2003) kadar air yang ada pada filtrat tape ketan sebesar $62.56 \%$. Kadar air dihasilkan dari proses fermentasi tape ketan, fermentasi yang tidak mengalami penghambatan menghasilkan air yang semakin banyak (Fardiaz, 1996). Kadar pati menunjukkan sisa pati yang belum mengalami perubahan biokimiawi akibat aktifitas mikroba selama fermentasi. Hasil analisa menunjukkan nilai kadar pati sebesar $2.36 \%$. Perbedaan nilai kadar pati dapat disebabkan oleh jumlah ragi yang digunakan untuk proses fermentasi sehingga dapat terjadi perbedaan (Djajati dkk, 2009).

Hasil analisa total gula pada Tabel 1 sebesar $65.80 \%$, Hidayat dkk (2004) menyatakan sebagian besar komponen yang memadat pada brem adalah gula. Kadar total asam yang terkandung pada filtrat tape ketan hasil analisa yaitu $0.436 \%$. Menurut (Widjajaseputra,1998) selama fermentasi tape berlangsung penguraian pati menjadi gula-gula sederhana oleh kapang, kemudian gula-gula yang terbentuk sebagian akan diubah menjadi alkohol oleh khamir, selanjutnya sebagian alkohol yang terbentuk diubah menjadi asam organik, yang menjadikan produk brem padat yang dihasilkan dari pengolahan cairan tape ini akan memiliki rasa manis, berbau alkohol dan sedikit masam.

\section{Hasil Analisa Respon Optimasi}

Optimasi merupakan suatu metode untuk mencapai hasil terbaik dari suatu rancangan percobaan tertentu. Metode ini merupakan metode statistik modern yang digunakan untuk mendesain suatu percobaan agar dapat mencapai tujuan eksperimental yang diinginkan dengan menggunakan biaya seminimal mungkin (Arteaga et al., 1996). 
Tabel 2. Hasil Analisis Respon Penambahan Maltodekstrin

\begin{tabular}{ccccccc}
\hline Std & Run & $\begin{array}{c}\text { Variabel } \\
\text { Kode }\end{array}$ & $\begin{array}{c}\text { Variabel } \\
\text { Bebas }\end{array}$ & $\begin{array}{c}\text { Rendemen } \\
\text { Maltodekstrin } \\
(\%)\end{array}$ & $\begin{array}{c}\text { Total } \\
\text { Gula } \\
(\%)\end{array}$ & $\begin{array}{c}\text { Tekstur } \\
\left(\mathbf{k g} / \mathbf{c m}^{2}\right)\end{array}$ \\
\hline 8 & 1 & 0.000 & 0.00 & 21.35 & 66.79 & 8.20 \\
4 & 2 & 0.500 & 0.00 & 23.90 & 67.60 & 9.50 \\
7 & 3 & 0.000 & 0.15 & 25.96 & 70.00 & 11.25 \\
9 & 4 & 0.000 & 0.30 & 28.50 & 71.09 & 22.10 \\
3 & 5 & -0.500 & 0.30 & 31.07 & 71.75 & 24.10 \\
5 & 6 & 1.000 & 0.30 & 31.53 & 71.88 & 19.60 \\
6 & 7 & 1.000 & 0.45 & 34.33 & 73.50 & 26.20 \\
2 & 8 & -1.000 & 0.60 & 36.00 & 81.13 & 43.79 \\
1 & 9 & -1.000 & 0.60 & 36.16 & 85.03 & 45.00 \\
\hline
\end{tabular}

\section{Rendemen}

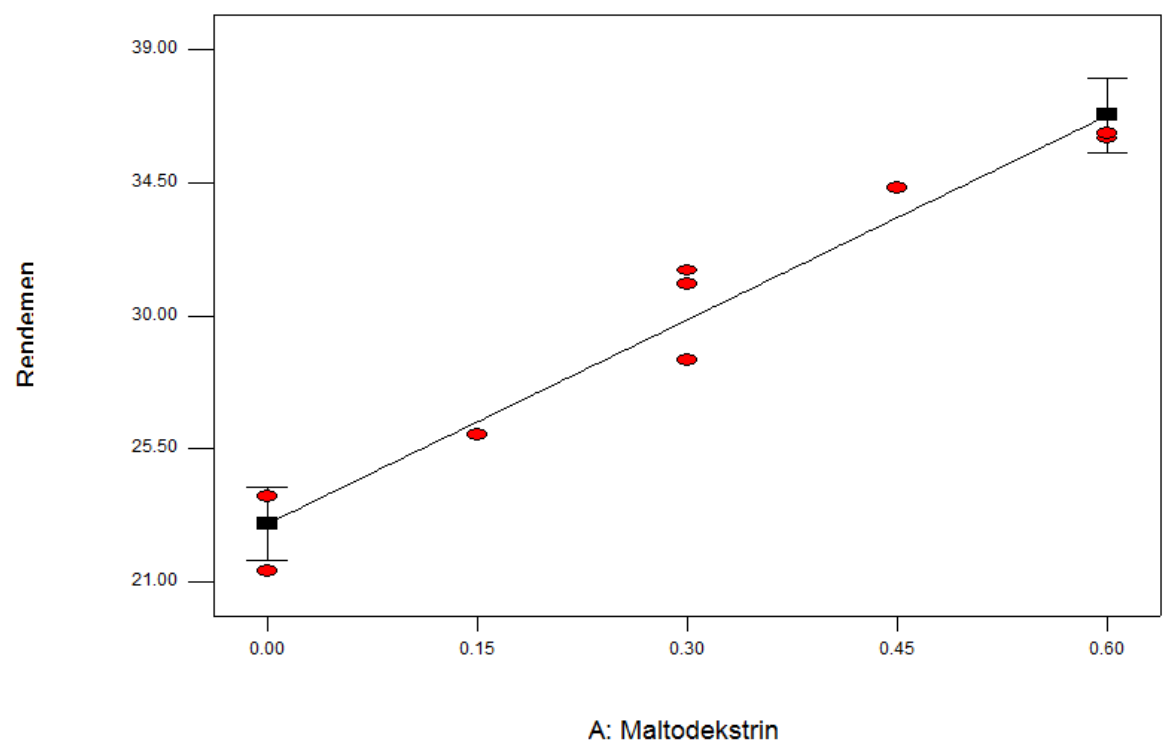

Gambar 1. Grafik Respon Rendemen Terhadap Penambahan Kadar Maltodekstrin pada Design Expert 7.1.5

Grafik respon rendemen apda Gambar 1 menunjukkan bahwa penambahan kadar maltodekstrin berpengaruh terhadap peningkatan jumlah rendemen yang dihasilkan. Peningkatan dimulai dari penambahan kadar maltodekstrin sebesar $0.15 \%$ hingga $0.60 \%$ dimana rendemen berbanding lurus dengan besarnya maltodekstrin yang ditambahkan. Dapat disimpulkan bahwa semakin banyak kadar maltodekstrin yang ditambahkan maka rendemen yang dihasilkan akan semakin meningkat. Hal tersebut dikarenakan maltodekstrin berfungsi sebagai bahan pengisi (filler) yang dapat meningkatkan jumlah total padatan, sehingga pada brem yang ditambahkan kadar maltodekstrin dengan jumlah yang banyak maka rendemen yang dihasilkan akan bertambah, dikarenakan total padatan yang akan bertambah seiring banyaknya maltodekstrin yang ditambahkan. Menurut (Master, 1979 dalam Siska 2015) Maltodekstrin merupakan bahan yang ditambahkan pada proses pengolahan pengan untuk melapisi komponen-komponen flavor, meningkatkan jumlah total padatan, memperbesar volume, mempercepat proses pengeringan dan mencegah kerusakan bahan akibat panas 


\section{Total Gula}

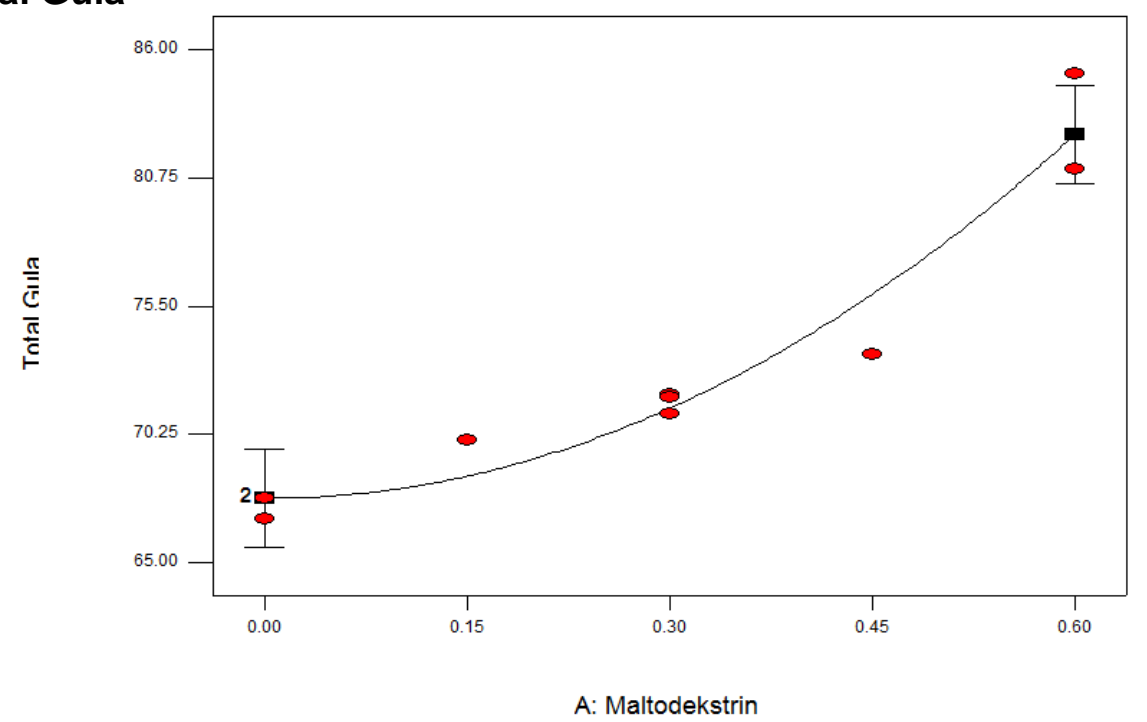

Gambar 2. Grafik Respon Total Gula Terhadap Kadar Maltodekstrin yang Dihasilkan oleh Program Design Expert 7.1.5.

Gambar 2 memberikan informasi bahwa semakin banyak kadar maltodekstrin yang digunakan maka total gula yang dihasilkan semakin tinggi. Pada penambahan maltodekstrin $0 \%$ menghasilkan rata-rata total gula sebesar $67.165 \%$, kemudian terjadi peningkatan nilai total gula seiring bertambahnya kadar maltodekstrin. Penambahan maltodekstrin sebanyak $0.60 \%$ menghasilkan rata-rata total gula sebesar $83.08 \%$. Peningkatan nilai total gula dipengaruhi oleh banyaknya kadar maltodekstrin yang ditambahkan, semakin banyak maltodekstrin yang ditambahkan maka nilai total gula akan semakin meningkat. Menurut (Whitsler and Miller, 1997) maltodekstrin merupakan senyawa hidrolisis pati yang tidak sempurna, terdiri dari campuran gula-gula dalam bentuk sederhana (mono dan disakarida) dalam jumlah kecil, oligosakarida dengan rantai pendek dalam jumlah relatif tinggi serta sejumlah kecil oligosakarida berantai panjang. Maltodekstrin yang digunakan pada penelitian ini memiliki nilai DE sekitar 15 20, yang berarti akan mudah larut dalam air. De Rovira (2008) menyatakan semakin besar nilai DE (Dextrose Equivalent) maka akan semakin besar pula jumlah gula atau semakin besar presentasi pati yang berubah menjadi gula. Sehingga, semakin banyak maltodekstrin ditambahkan akan semakin banyak pula jumlah gula yang tercampur karena pada dasarnya maltodesktrin terdiri dari gula-gula dalam bentuk sederhana yang menyebabkan nilai total gula bahan akan meningkat.

\section{Daya Patah}

Hasil analisa menunjukan bahwa kadar maltodekstrin yang ditambahkan berpengaruh terhadap daya patah brem. Peningkatan disebabkan semakin banyak maltodesktrin yang ditambahkan maka akan semakin cepat menyerap air dan menyebabkan tekstur pada brem akan semakin cepat mengkristal serta akan meningkatkan tingkat kekerasan dari brem. Maltodekstrin juga dapat meningkatkan total padatan bahan yang dikeringkan, sehingga jumlah air yang diuapkan semakin tinggi, akibatnya tingkat kekerasan (daya patah) dari brem akan semakin meningkat. Sesuai dengan Fennema (1996) semakin banyak bahan pengisi yang ditambahkan maka gugus-gugus hidroksil dari maltodesktrin (unit D-glukosa) akan membentuk ikatan hidrogen dengan molekul molekul air disekitarnya, sehingga semakin cepat terjadi pengkristalan dan penguapan air. 


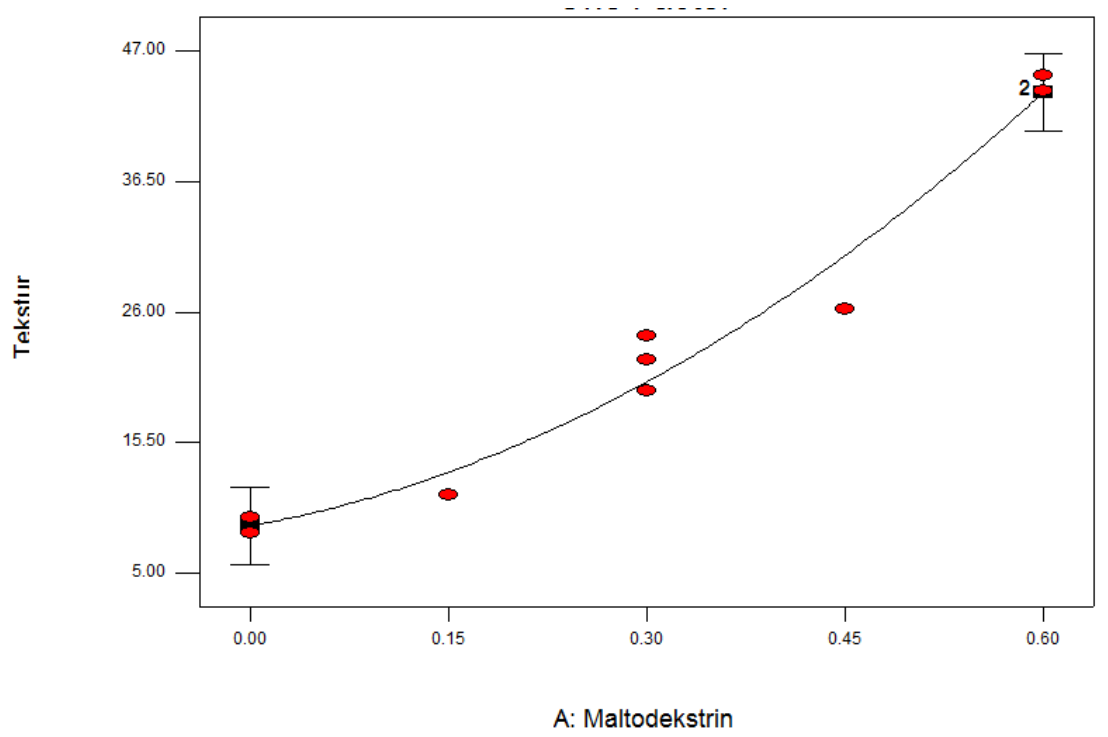

Gambar 3. Grafik Respon Daya Patah Terhadap Penambahan Kadar Maltodekstrin yang Dihasilkan oleh Program Design Expert 7.1.5.

\section{Hasil Penentuan Titik Optimum}

Penentuan titik optimum dilakukan berdasarkan kriteria yang kita inginkan dengan pemilihan kepentingan serta tujuan yang diinginkan terhadap respon serta faktor yang ada. Ketika kriteria ditentukan maka software Desain Expert 7.1.5 akan secara otomatis memberikan solusi yang optimum dari semua kriteria yang ada. Setelah menemukan titik optimum di lakukan tahap verifikasi dari solusi yang terdapat pada program dengan percobaan yang aktual. Penelitian ini memiliki satu faktor utama yaitu penambahan kadar maltodekstrin serta 3 respon yang mempengaruhi yaitu rendemen, total gula dan daya patah brem. Kriteria yang diinginkan adalah rendemen semaksimal mungkin, total gula semaksimal mungkin serta daya patah yang sesuai. Ketika semua kriteria terpilih sudah di tentukan software Design Expert 7.1.5 menghasilkan solusi titik optimum dengan kadar penambahan maltodekstrin sebesar $0,6 \%$.

Tabel 3.Solusi Titik Optimum dari Kriteria Terpilih pada Penambahan Maltodekstrin

\begin{tabular}{|c|c|c|c|c|c|}
\hline \multirow{2}{*}{$\begin{array}{c}\text { Maltodekstri } \\
\mathbf{n} \\
(\%)\end{array}$} & \multicolumn{3}{|c|}{ Respon } & \multirow[b]{2}{*}{ Desirability } & \multirow[b]{2}{*}{ Ket. } \\
\hline & $\begin{array}{c}\text { Rendeme } \\
\text { n (\%) }\end{array}$ & $\begin{array}{c}\text { Total Gula } \\
(\%)\end{array}$ & $\begin{array}{c}\text { Daya Patah } \\
\left(\mathrm{kg} / \mathrm{cm}^{2}\right)\end{array}$ & & \\
\hline 0.60 & 36.77 & 80.64 & 40.76 & 0.93 & Selectec \\
\hline
\end{tabular}

\section{Karakteristik Brem Optimal \\ Kadar Air}

Kadar air menjadi salah satu parameter utama yang menentukan kualitas produk kering seperti pada brem. Kadar air brem hasil optimasi memiliki kadar air sebesar $14.99 \%$, apabila dibandingkan dengan kadar air brem kontrol yaitu $16.49 \%$ maka kadar air brem hasil optimasi nilainya lebih rendah. Hal tersebut dikarenakan brem hasil optimasi ditambahkan maltodekstrin pada proses pembuatannya. Penambahan maltodekstrin menyebabkan kadar air pada brem semakin rendah, hal ini disebabkan 
maltodekstrin memiliki kemampuan untuk menyerap air. Maltodekstrin juga dapat meningkatkan total padatan bahan yang dikeringkan, sehingga jumlah air yang diuapkan semakin tinggi, akibatnya peningkatan konsentrasi maltodekstrin akan menurunkan kadar air produk brem. Hal tersebut sesuai dengan pendapat Masters (1979), semakin tinggi total padatan yang dikeringkan maka kecepatan penguapan akan semakin tinggi sehingga kadar air bahan menjadi rendah. Barbisa-Canovas (1999) menyatakan maltodekstrin akan membentuk ikatan hidrogen dengan molekul molekul air disekitarnya, maka ketika air dihilangkan akan terjadi pengkristalan, karena gugus hidroksil akan membentuk ikatan hidrogen dengan gugus hidroksil yang lain sesama monomer. Oleh karena itu semakin banyak maltodekstrin yang ditambahkan semakin cepat terjadi pengkristalan dan penguapan air, kadar air bahan akan semakin rendah.

Tabel 4 Perbandingan Brem Respon Optimum dengan Brem Kontrol

\begin{tabular}{lcc}
\hline \multirow{2}{*}{ Komponen } & \multicolumn{2}{c}{ Jenis Brem } \\
\cline { 2 - 3 } & $\begin{array}{c}\text { Brem Hasil } \\
\text { Optimasi }\end{array}$ & $\begin{array}{c}\text { Brem Kontrol (Merk } \\
\text { Suling Gading) }\end{array}$ \\
\hline Kadar Air (\%) & $14.99 \pm 0.25$ & 16.49 \\
Total Gula (\%) & $81.51 \pm 0.5$ & 67.22 \\
Total Asam (\%) & $0.78 \pm 0.03$ & 0.41 \\
Daya Patah (kg/cm $\left.{ }^{2}\right)$ & $41.85 \pm 0.86$ & 26.52 \\
Kecepatan Larut $(\mathrm{gr} /$ detik) & $0.04 \pm 0.001$ & 0.03 \\
\hline
\end{tabular}

\section{Total Gula}

Total gula berpengaruh terhadap rasa manis yang dihasilkan oleh brem. Brem yang bermutu tinggi diharapkan meiliki rasa manis yang tinggi, sehingga total gula akan sangat berpengaruh tehadap mutu dan rasa brem. Total gula brem hasil optimasi memiliki nilai yang lebih tinggi apabila dibandingkan dengan total gula brem kontrol. Brem hasil optimasi memiliki nilai total gula sebesar $81.51 \%$ sedangkan brem kontrol memiliki total gula sebesar $67.22 \%$. Peningkatan nilai total gula dipengaruhi oleh banyaknya kadar maltodekstrin yang ditambahkan, semakin banyak maltodekstrin yang ditambahkan maka nilai total gula akan semakin meningkat. Menurut (Whitsler and Miller, 1997) maltodekstrin merupakan senyawa hidrolisis pati yang tidak sempurna, terdiri dari campuran gula-gula dalam bentuk sederhana (mono dan disakarida) dalam jumlah kecil, oligosakarida dengan rantai pendek dalam jumlah relatif tinggi serta sejumlah kecil oligosakarida berantai panjang. Maltodekstrin yang digunakan pada penelitian ini memiliki nilai DE sekitar 15 - 20, yang berarti akan mudah larut dalam air. De Rovira (1999) menyatakan semakin besar nilai DE (Dextrose Equivalent) maka akan semakin besar pula jumlah gula atau semakin besar presentasi pati yang berubah menjadi gula. Sehingga, semakin banyak maltodekstrin ditambahkan akan semakin banyak pula jumlah gula yang tercampur karena pada dasarnya maltodesktrin terdiri dari gula-gula dalam bentuk sederhana yang menyebabkan nilai total gula bahan akan meningkat.

\section{Total Asam}

Salah satu rasa khas dari brem adalah masam, rasa masam ini berasal dari peruraian pati menjadi gula-gula sederhana saat proses fermentasi, kemudian gula-gula yang terbentuk sebagian akan diubah menjadi alkohol oleh khamir, dan sebagian alkohol yang terbentuk diubah menjadi asam-asam organik yang menjadikan produk brem akan memiliki rasa manis, berbau alkohol dan sedikit masam. Nilai total asam brem hasil optimasi sebesar $0.78 \%$ sedangkan brem kontrol memiliki nilai total asam yang lebih 
rendah yaitu $0.41 \%$. Perbedaan nilai total asam ini dikarenakan pada saat pembuatan brem hasil optimasi ditambahkan sari buah jeruk. Sari buah jeruk memiliki tingkat keasaman yang cukup tinggi, sehingga dapat berpengaruh terhadap nilai total asam brem. Menurut (Santoso, 2000) semakin banyak perbandingan sari buah jeruk yang ditambahkan maka nilai total asam produk akan bertambah dikarenakan buah jeruk mengandung asam sitrat dan asam malat yang memberi rasa masam pada buah jeruk. Sesuai dengan Salunkhe dan Kadam (1995) menyatakan bahwa jeruk termasuk kedalam acid fruits dengan padatan terlarut yang sebagian besar terdiri dari asam-asam organik dan gula. Berdasarkan hal tersebut maka dapat diketahui bahwa penambahan sari buah jeruk pada pembuatan brem dapat meningkatkan nilai total asam yang dihasilkan.

\section{Daya Patah}

Penambahan maltodekstrin pada pembuatan brem juga berpengaruh terhadap tekstur brem yang dihasilkan. Brem hasil optimasi menghasilkan nilai daya patah sebesar $41.85 \mathrm{~kg} / \mathrm{cm}^{2}$. Apabila dibandingkan dengan daya patah dari brem kontrol yang memiliki nilai daya patah sebesar $26.52 \mathrm{~kg} / \mathrm{cm}^{2}$, maka daya patah brem hasil optimasi mengalami peningkatan. Peningkatan disebabkan semakin banyak maltodesktrin yang ditambahkan maka akan semakin cepat menyerap air dan menyebabkan tekstur pada brem akan semakin cepat mengkristal serta akan meningkatkan tingkat kekerasan dari brem. Maltodekstrin juga dapat meningkatkan total padatan bahan yang dikeringkan, sehingga jumlah air yang diuapkan semakin tinggi, akibatnya tingkat kekerasan tekstur dari brem akan semakin meningkat. Sesuai dengan Fennema (1996) semakin banyak bahan pengisi yang ditambahkan maka gugus-gugus hidroksil dari maltodesktrin (unit D-glukosa) akan membentuk ikatan hidrogen dengan molekul molekul air disekitarnya, sehingga semakin cepat terjadi pengkristalan dan penguapan air

\section{Kecepatan Larut}

Laju kelarutan sangat berpengaruh terhadap kualitas brem, brem yang baik memiliki kelarutan yang tinggi karena akan mudah larut di dalam mulut. Daya larut yang cepat menjadi salah satu ciri khas brem. Menurut (Hidayat dkk, 2004) brem dengan kualitas yang baik akan mudah larut didalam mulut. Laju kelarutan brem hasil optimasi sebesar $0,04 \mathrm{~g} /$ det. Apabila dibandingkan dengan laju kelarutan brem kontrol $(0.03 \mathrm{~g} / \mathrm{det})$ maka laju kelarutan brem hasil optimasi lebih tinggi. Perbedaan laju kelarutan ini disebabkan karena perlakuan penambahan maltodekstrin pada brem hasil optimasi. Pada saat brem hasil optimasi dilarutkan maka gugus hidroksil yang terdapat dalam maltodekstrin akan berinteraksi dengan sehingga kelarutan brem akan meningkat. Alexander (1992) menyatakan bahwa semakin banyak gugus hidroksil bebas pada bahan pengisi maka semakin tinggi pula tingnkat kelarutannya. Sesuai dengan Hui (1992) sifat yang dimiliki maltodesktrin yaitu mengalami proses dispersi yang cepat dan memiliki daya larut yang tinggi. Selain faktor penambahan maltodesktrin yang dapat meningkatkan laju kelarutan brem, kadar air brem juga mempengaruhi laju kelarutan. Kadar air yang rendah akan menyebabkan brem memiliki kemungkinan lebih porus dibanding brem dengan kadar air yang lebih tinggi, sehingga kemampuan untuk menyerap air akan lebih besar dan kelarutannya pun akan menjadi lebih besar. Menurut (Hardjanti, 2008) kadar air yang rendah pada suatu produk mengakibatkan produk tersebut menjadi lebih higroskopis dan mudah menyerap air sehingga kelarutan produk dalam air juga akan semakin besar.

\section{SIMPULAN}

Optimasi penambahan maltodekstrin pada pembuatan brem padat dengan flavour buah (kajian: penambahan kadar maltodekstrin) menunjukkan bahwa penambahan maltodekstrin berpengaruh nyata terhadap respon rendemen, total gula, dan tekstur. 
Kondisi optimum penambahan maltodekstrin pada pembuatan brem dengan flavour buah yang diinginkan dengan kriteria rendemen yang maksimum, total gula maksimum, dan tekstur in range adalah pada penambahan maltodekstrin sebanyak $0.60 \%$. Analisa respon pada kondisi optimum menghasilkan rendemen $35.93 \%$, total gula $81.51 \%$, dan tekstur sebesar $41.85 \mathrm{~kg} / \mathrm{cm}^{2}$.

\section{DAFTAR PUSTAKA}

Alexander, R.J. 1992. Maltodextrin : Production, Properties, and Application. VCH Publishers, New York

Arteaga, G. E., Li-Chan, E., Vazquez-Arteaga, M. C. and Nakai, S. 1996. Systematic experimental designs for product formula optimization. Trends in Food Science and Technology 5, 243-254.

Barbosa-Canovas. 1999. Food Processing : Biological aspects. Marcel Dekker. New York

De Rovira, Dolf. 2008. Dictionary of flavours. Wiley-Blackwell. U.S. Library of Congress

Djajati, Sri dkk. 2009. Pembuatan Brem Padat Dengan Substitusi Filtrat Tape Umbi Talas. Jurnal Pangan Jurusan Teknologi Pangan, Fakultaas Teknologi Industri. UPN "Veteran" Jawa Timur

D.K. Salunkhe and S.S Kadam. 1995. Fruit Science and Technology : Production, Composition, Storage, and Processing. Marcel Dekker, Inc. New York

Fardiaz. 2006. Kimia Flavour I. Jurusan Kimia, Fakultas Teknik. Medan : Universitas Sumatera Utara.

Fennema. 1996. Food Chemistry. 3th Edition. New York: Marcel Dekker, Inc.

Fardiaz, S., Sasmito, Y. A. dan Sugiyono., 1996. Studi Fermentasi Tape Rendah Alkohol. Jurnal IImu dan Teknologi Pangan, $1: 1,27$ - 33

Hardjanti, Sri. 2008. Potensi Daun Katuk Sebagai Sumber Zat Pewarna Alami dan Stabilitasnya Selama Pengeringan Bubuk dengan Menggunakan Binder Maltodekstrin. Jurnal Penelitian Saintek, 13:1, 1-18

Hidayat. 2004. Pembuatan Brem Aneka Rasa. www.nurhidayat.lecture.ub.ac.id. Tanggal aksee: 22/05/2016

Hui, Y.H., 1992. Encyclopedia of Food Science and Technology. Jhon Wiley and Sons Inc. New York.

Masters K. 1979. Spray Drying Handbook. John Wiley and Sons Co.New York. Page 687.

Primarini, D. 1995. Studi tentang Enzim Amilase Penghidrolisis Pati Mentah Ubi Kayu dari Stretomyces sp no.4. Bioteknologi Biomassa BPPT

Santoso, H. B. 2000. Sari Buah Nanas dan Jeruk. Kanisius, Yogyakarta

Sasmito, Y. A. dan Sugiyono., 1996. Studi Fermentasi Tape Rendah Alkohol. Jurnal Ilmu dan Teknologi Pangan, 1 (1) : 27 - 33

Setyobudi, Dondy A. 2011. Sinar Tani. Badan Litbang Pertanian. Edisi 16-22 September 2011. No. 3431 Tahun XLII

Setyorini, 2003. Pengaruh Proporsi air Tape (Ubi Jalar dan Ketan) dan Lama Pengadukan Terhadap Kualitas Brem Padat. Skripsi Jurusan Teknologi Hasil Pertanian. Fakultas Teknologi Pertanian. Universitas Brawijaya. Malang

Sudarmadji, S. dkk. 1990. Mikrobiologi Pangan. PAU Pangan dan Gizi. Universitas Gadjah Mada.

Susanto, T. dan B. Saneto, 1994. Teknologi Pengolahan Hasil Pertanian. Bina IImu, Surabaya.

Tranggono. 1990. Bahan Tambahan Pangan (Food Additives). Pusat antar UniversitasPangan dan Gizi. Univesitas Gadjah Mada. h. 191-192. 
Wangtueai, S. and Noomhorm, A. 2009. Processing optimization and characterization of gelatin from lizardfish (Saurida spp.) scales. LWT- Food Science and Technology 42: 825-834.

Whistler RL, and BeMiller JN. 1997. Carbohydrate Chemistry for Food Scientist. American Association of Cereal Chemist.

Widjajaseputra, A.I. 1998. Kajian Bahan Pensubstitusi Beras ketan Pada Produk Brem Padat. Jurnal IImiah Widya Mandala, 5:4 